\title{
EXPORT PRIORITIES FOR THE DEVELOPMENT OF THE NON-OIL SECTOR OF THE REPUBLIC OF AZERBAIJAN
}

\author{
Ayten Mekhraliyeva ${ }^{*}$, Elshad Mamedov ${ }^{2}$ \\ ${ }^{1}$ Ph.D. candidate in Economics, independent researcher, the member of Science Center attached to \\ Russian Economic School at UNEC, Azerbaijan State University of Economics (UNEC), AZ1007, A. \\ Sahhat str., 45 A, Baku, AZ1007, Azerbaijan, aytenmekhraliyeva18@mail.ru , (+994 55) 7599467 \\ ${ }^{2}$ Doctor of Economics, professor, Azerbaijan State University of Economics (UNEC), AZ1007, A. Sahhat \\ str., 45 A, Baku, AZ1007, Azerbaijan
}

\begin{abstract}
The article examines the significance of the development of the non-oil sector in Azerbaijan. The potential of this industry segment is analyzed in comparison with other sectors of the economy. The study reveals the main reasons for regression in technological, infrastructural and staffing. Export potential is an integral part of the country's economic potential. The ability of the national economy and its individual branches depends on it, as a result of the full use of the means of production, to produce and export goods and services in the quantity and quality that corresponds to the demand of consumers in the external market. It should be noted that there is a demand for export. If we take into account that the number of products that can be produced in the country is quite small compared to the number of products on the world market, then we can assume that there will always be a potential demand for the country's oil products. Consequently, if the price of a product on the domestic market is less than its price on the world market, then there is an export potential. The article studies the specifics of regulating the country's export potential, as well as an analysis of the export structure.
\end{abstract}

\section{Keywords}

Integration, globalization, government regulation, non-oil sector, export policy, economic development

\section{JEL Classification}

F63, G18, G38

DOI: $\underline{\text { https://doi.org/10.14311/bit.2021.01.07 }}$

Editorial information: journal Business \& IT, ISSN 2570-7434, CreativeCommons license (c) (i) published by CTU in Prague, 2021, http://bit.fsv.cvut.cz/

\section{Introduction}

The transformation of Azerbaijan into a major exporter of oil, an increase in its production from year to year, the dynamic growth of foreign exchange earnings due to exports in this sector have brought into focus the need to increase export potential and other spheres of the economy. Taking as a basis the factors of the negative impact of the outstripping growth of oil revenues, as well as the depletion of oil reserves in the future, the government declared the development of the non-oil sector a priority of economic policy. To solve this problem and implement state support in this area, numerous programs 
have been adopted and partially implemented in recent years. One of them is the State Program of Socio-Economic Development of Regions of the Republic of Azerbaijan in 2008-2013. The main goals of the planned are to ensure the development of non-oil industries, including processing, as well as to increase the production of agricultural products based on the effective use of the wealth and natural conditions of the regions. Of the macroeconomic measures, the adoption of which is provided for in the document, of particular importance for the development and increase in the export potential of the non-oil sector have the following [4]:

$>$ improving the legislative framework, including the creation of special economic zones in the country, the expansion of investment activities, the development of draft laws regulating antimonopoly and other economic relations, stimulating the development of regions;

$>$ increasing financial support for projects of socio-economic development of regions;

$>$ reduction of tax rates to optimal level;

$>$ continuation of the policy of applying tax holidays to agricultural producers;

$>$ further preservation of customs rates at the optimal level;

$>$ creation of large customs terminals and free customs zones in the north, south and western directions of the Republic of Azerbaijan, as well as around Baku;

$>$ improving the activities of the National Fund for Assistance to Entrepreneurship;

$>$ creation and development of a network of agrotechnical services;

$>$ continuation of measures of state financial assistance to enterprises of the agro-industrial complex, farms, etc.

Among the non-oil sector of Azerbaijan, agriculture differs both in export potential and in the level of use of this potential and has a special weight. From this point of view, the significance of this program can hardly be overestimated. The provision of state support in the sale of products grown by farmers both in domestic and foreign markets, the creation of an Export Assistance Fund, stock exchanges, wholesalers, auctions has become one of the main tasks identified in the document in connection with this industry.

\section{Methodology}

Research methods are general scientific methods of cognition - analysis, synthesis, induction and deduction, comparison; research tools for observation and data aggregation; and statistical analysis. Classical and modern theories related to international trade, reflected in the works of famous scientists, economists from near and far abroad, as well as Azerbaijani scientists are the information base of the study. In addition, in the final work, Decrees of the President, State Programs adopted in the country, data of the State Committee on Statistics, the Customs Committee, etc. were used.

\section{The program of socio-economic development of regions}

At the beginning of gaining independence, the Republic of Azerbaijan chose a strategy for the development of the oil sector of the economy. At that time, oil was the only resource that the country could offer on world markets and the only area where foreign investment could be attracted. Thus, Azerbaijan turned into an exporter of oil, the sale of which made up the bulk of the country's export. However, the unilateral development of the economy has a negative impact on the economy, depletes a non-renewable resource, and also increases the risks of losses from changes (decrease) in prices for this resource in world markets. All of the above makes the development of the non-oil sector of the economy urgent. To support the development of the non-oil sector of the economy, various programs have been adopted in the country, which include the Program of Socio-Economic Development of 
Regions, which was implemented in 3 stages 2004-2008; 2009-2013 and 2014-2018. Within the framework of this Program, infrastructure projects were implemented, the production of agricultural products, the processing industry, the efficient use of resources, the creation of new jobs, an increase in the standard of living, etc.

Over the years of implementation of this program, the legal framework for business development in the regions of the country has been improved, opportunities for investment activities have been expanded, and measures have been taken against the expansion of monopoly activities. During the implementation of the programs, the financial support of the socio-economic development of the regions improved, and taxation was improved. Thus, tax rates were reduced, tax holidays were applied for agricultural producers. The National Fund for Assistance to Entrepreneurship was actively involved in the processes of regional development, as well as state financial assistance was provided to farms and enterprises of the agro-industrial complex. At the same time, a policy of maintaining customs rates at an optimal level was pursued, which stimulated the development of regions and an increase in their export potential. An important role in the development of the export potential of the agricultural sector was played by the creation of the Export Assistance Fund, which provided support in the promotion of agricultural products in foreign markets.

The success of the implementation of 3 regional development programs indicates the need for their continuation. In this regard, on behalf of the President of the Republic of Azerbaijan, the 4th state program of socio-economic development of regions for 2019-2023 is being prepared. Consider the dynamics of exports for food products, tobacco and alcoholic beverages in Azerbaijan for 2007-2017 (Table 1). The analysis shows that for 2007-2017, different trends can be traced for different product groups, for some there is an increase in exports, for others, on the contrary, a decrease. The goods, the export of which is growing, include fresh vegetables and natural grape wines, the volume of sales of which during the study period increased 4.4 times and 2.2 times, respectively. Export growth is also observed for such product groups as fresh fruits - by $36.2 \%$; canned fruits and vegetables - $76.4 \%$ and tobacco - by $17.9 \%$. For the rest of the commodity groups for $2007-2017$ there is a decrease in exports. Thus, the export of potatoes decreased by $8.5 \%$; tea by $61.0 \%$; vegetable oil by $57.9 \%$; fat by $86.7 \%$; granulated sugar by $79.0 \%$; fruit and vegetable juices - $66.3 \%$; spirits by $54.9 \%$; cigarettes by $86.3 \%$. For comparison, consider the import structure.

Table 1. Dynamics of export of food products for 2007-2017 in the AR (Source: compiled by the author based on data from the State Statistics Committee)

\begin{tabular}{|l|l|l|l|l|l|l|l|}
\hline \multicolumn{1}{|c|}{ Product name } & \multicolumn{1}{|c|}{$\mathbf{2 0 0 7}$} & $\mathbf{2 0 0 9}$ & $\mathbf{2 0 1 1}$ & \multicolumn{1}{|c|}{$\mathbf{2 0 1 3}$} & \multicolumn{1}{|c|}{$\mathbf{2 0 1 5}$} & \multicolumn{1}{|c|}{$\mathbf{2 0 1 7}$} & $\begin{array}{c}\text { Growth } \\
\text { (\%) }\end{array}$ \\
\hline Potatoes (tons) & 62975,8 & $\mathbf{8 5} 519,5$ & 91719,8 & 53936,5 & 36712 & 57597,2 & 91,5 \\
\hline $\begin{array}{l}\text { Fresh vegetables } \\
\text { (tons) }\end{array}$ & 52187,4 & 64406,1 & 65789,4 & 65518,5 & 83312,5 & 229697,2 & 441,1 \\
\hline Fresh fruits (tons) & 191390,0 & 232794,6 & 176221,6 & 173239,3 & 172980,9 & 260712,2 & 136,2 \\
\hline Tea (tons) & 5988,4 & 6266,4 & 7520,4 & 7585,8 & 4287,5 & 1735,0 & 29,0 \\
\hline Wheat flour (tons) & 9358,7 & 13698,8 & - & - & 57,0 & 11,0 & 0,1 \\
\hline Vegetable oil (tons) & 22545,0 & 21137,0 & 24015,6 & 36992,3 & 23469,2 & 9491,7 & 42,1 \\
\hline Fats and oils (tons) & 27395,7 & 21509,8 & 30398,9 & 29112,3 & 25463,8 & 3630,6 & 13,3 \\
\hline $\begin{array}{l}\text { Margarine and other } \\
\text { edible oils (tonnes) }\end{array}$ & 12275,7 & 11909,4 & 14606,8 & 20190,0 & 27195,7 & 2630,9 & 21,4 \\
\hline $\begin{array}{l}\text { Granulated sugar } \\
\text { (tons) }\end{array}$ & 291,4 & 177,0 & 221,7 & 249,3 & 220,8 & 61,2 & 21,0 \\
\hline
\end{tabular}




\begin{tabular}{|l|l|l|l|l|l|l|l|}
\hline $\begin{array}{l}\text { Canned fruits and } \\
\text { vegetables }\end{array}$ & 3372,9 & 4417,5 & 5331,7 & 8712,5 & 2880,1 & 5950,5 & 176,4 \\
\hline $\begin{array}{l}\text { Fruit and vegetable } \\
\text { juices (thousand dkl.) }\end{array}$ & 40869,5 & 22658,4 & 13744,4 & 9826,8 & 6727,2 & 9627,2 & 23,6 \\
\hline $\begin{array}{l}\text { Natural grape wines } \\
\text { (thousand dkl.) }\end{array}$ & 167,6 & 142,0 & 338,4 & 409,4 & 194,5 & 375,0 & 223,7 \\
\hline Spirits, (thous. dkl.) & 866,2 & 322,9 & 230,1 & 602,2 & 369,8 & 390,9 & 45,1 \\
\hline Tobacco (tone) & 3891,6 & 1767,1 & 2872,1 & 3458,7 & 1944,4 & 4586,3 & 117,9 \\
\hline $\begin{array}{l}\text { Cigarettes (million } \\
\text { pieces) }\end{array}$ & 648,2 & 206,2 & - & - & 158,4 & 88,8 & 13,7 \\
\hline
\end{tabular}

As can be seen from Table 2, the development of a natural gas field and access to foreign markets resulted in a very large increase in exports for this product group.

Table 2. Dynamics of exports by commodity groups for 2007-2017 in the AR (Source: compiled by the author based on data from the State Statistics Committee)

\begin{tabular}{|c|c|c|c|c|c|c|c|}
\hline Product name & 2007 & 2009 & 2011 & 2013 & 2015 & 2017 & $\begin{array}{l}\text { Growth } \\
\text { (\%) }\end{array}$ \\
\hline Crude oil (TMT) & 6313.7 & 27829.5 & 27825.3 & 24855.9 & 21960.3 & 27227.9 & 431.3 \\
\hline Automobile gasoline (TMT) & 332.5 & 254.4 & 96.5 & 24.6 & 4.7 & 7 & 2.1 \\
\hline Kerosene for jet engines. (TMT) & 314.8 & 1045.8 & 243.5 & 252.9 & 333.1 & 181 & 57.5 \\
\hline Heavy distillers (TMT) & 1455.5 & 1577.4 & 1359.1 & 1084.8 & 1731.5 & 603.2 & 41.4 \\
\hline Natural gas (million m3) & 151.2 & 671.7 & 2885.8 & 3035.1 & 8432.7 & 7543.5 & 4989.1 \\
\hline $\begin{array}{l}\text { Natural gas according to reports } \\
\text { of State Oil Company of } \\
\text { Azerbaijan Republic (mln.m3.) }\end{array}$ & - & - & 6817.4 & 7308.0 & 8145.2 & 8859.7 & - \\
\hline Liquid fuel (TMT) & 926.3 & 183.4 & 213.1 & 228.3 & 113.4 & 23.3 & 2.5 \\
\hline Lubricating oils (tons) & 52382.5 & 34115.5 & 72632.3 & 40467.3 & 14928.9 & 20931.3 & 40 \\
\hline Petroleum coke, tons & 82700.4 & - & - & - & - & - & 311.1 \\
\hline Electricity, million $\mathrm{kW}$ & 443.3 & 710.4 & 794.5 & 595.7 & 293.8 & 1160.2 & 261.7 \\
\hline Acyl alcohol, its derivatives, tons & 15148.5 & 7796.00 & 12604.3 & 14193.7 & 115450.4 & 116780.2 & 1758 \\
\hline $\begin{array}{l}\text { Ethylene polymers in initial form, } \\
\text { tons }\end{array}$ & 30231.4 & 38482.1 & 60699.4 & 65572.7 & 88388.5 & 75803.8 & 2507 \\
\hline $\begin{array}{l}\text { Skins of large horned animals, } \\
\text { thousand pieces }\end{array}$ & 549.5 & 622.7 & 877.1 & 1060.3 & 850.3 & 422.9 & 77 \\
\hline $\begin{array}{l}\text { Raw skins of sheep and lamb, } \\
\text { thousand pieces }\end{array}$ & 1361.00 & 846.3 & 1734.1 & 1912.00 & 1447.3 & 886.1 & 65.1 \\
\hline $\begin{array}{l}\text { Paper and cardboard, products } \\
\text { from them, tons }\end{array}$ & 3399.2 & 3790.6 & 22465.4 & 3389.6 & 2168.5 & 24.9 & 0.7 \\
\hline Cotton fiber, tons & 34006.3 & 17278.00 & 2609.2 & 3973.2 & 4636.9 & 22024.9 & 64.8 \\
\hline Cotton yarn tons & 6760.3 & 7828.1 & 6524.6 & 11954.5 & 8431.1 & 7028.6 & 104 \\
\hline $\begin{array}{l}\text { Synthetic fabrics from comb, } \\
\text { threads thousand } \mathrm{m} 2\end{array}$ & 27954.7 & 17571.1 & 21556.9 & 11587.00 & 6560.6 & 4792.6 & 17.1 \\
\hline Yarn bags and bags (tons) & 6141.8 & 5333.2 & 8581.5 & 8501.3 & 6602.3 & 7359.3 & 119.8 \\
\hline $\begin{array}{l}\text { Semi-finished products from } \\
\text { ferrous metals. (tons) }\end{array}$ & 31950.1 & 17113.00 & - & 86334.3 & 65665.6 & 76575.5 & 239.7 \\
\hline Ferrous metal products, tons & 6835.5 & 420 & 59.6 & 0.1 & 4449.3 & 21054.3 & 308 \\
\hline
\end{tabular}




\begin{tabular}{|l|c|c|c|c|c|c|c|}
\hline $\begin{array}{l}\text { Angles and channels made of } \\
\text { ferrous metals, tons }\end{array}$ & 60729.6 & 27789.1 & 2207.8 & - & 61.7 & 3457.5 & 5.7 \\
\hline Raw aluminum, tons & 41612.1 & 13398.7 & 9859.3 & 54304.4 & 56121.9 & 31620.4 & 76 \\
\hline
\end{tabular}

Also, a significant increase takes place in the export of acetyl alcohol - 17.6 times; crude oil - 4.3 times; oil coconut - 3.1 times; products made of ferrous metals - 3.1 times; electricity - 2.6 times; ethylenepropylene - 2.5 times; semi-finished products from ferrous metals - by 2.4 times. In addition to the above product groups, a small increase in export volumes takes place in the export of bags and packages made of yarn - by $19.8 \%$ and cotton yarn - by $4.0 \%$. For the rest of the commodity groups, a decrease in export volumes is observed. A significant reduction takes place in the export of paper, cardboard and products from them, motor gasoline, liquid fuel, corners and channel bars made of ferrous metals, the export of which compared to 2007 is practically zero. The export of kerosene for engines and heavy distillers has almost halved and more. A significant decrease in exports was observed in unprocessed sheep skins, cotton fiber, synthetic fabrics from zombie threads. Analysis of imports shows for which commodity groups it is important to carry out a substitution import policy. It should be noted that agricultural products represent a significant part of the export of the non-oil sector. In recent years, this industry can be called one of the fastest growing.

World Bank experts note that Azerbaijan is among the reformer countries and ranks 25 th among them. The agricultural sector occupies an important place among the reformed sectors. Over the years of reforms that covered 2003-2017, there has been a real growth in the production of agricultural products, both crop and livestock production. It should be noted that, according to the estimates of the World Bank experts, the growth in agricultural production is ahead of the world average growth in this production.

For the further development of this sector, an increase in loans to the agricultural sector is expected. The planting of orchards also plays a special role in the development of agriculture. Considering that in this sector the export of fresh fruits, fruit juices, and grape wines is increasing at an accelerated rate and the export potential is higher, then we can say that this is of the greatest importance.

Currently, the development of the agricultural sector faces new challenges, the key of which is the development of the agro-industrial complex, the introduction of new technologies for the transition to the intensive development of agriculture. The transition to intensive development will contribute to the growth of export opportunities.

Within the framework of this program, it is planned to create agricultural parks, large farms. This direction is possible with increasing investments, which is provided for by the measures taken by the government of the country to support the creation of agricultural parks and the development of agriculture. The presence of large farms and agricultural parks in the country is one of the important conditions for increasing the export potential of Azerbaijan.

In connection with the need to enlarge farms, a system of their preferential crediting is envisaged.

President of the Republic of Azerbaijan I. Aliyev approved the decree "On improving leasing activities in the agricultural sector and state support for agriculture." According to this decree, entrepreneurs operating in the agricultural sector will have access to preferential loans. The country has created the Agency for Agricultural Credits and Development, which will issue loans for the development of agriculture. This agency can open a credit line for banks, the maximum size of which is 5 million manat.

It should be noted that the size of loans has increased. If earlier the size of micro loans was up to 1,000 manats, now it has increased to 5,000 manats. The size of small loans also increased, which amounted to 1,000 to 20,000 , and now increased to 5,001 to 30,000 manats. Medium size loans increased from 20,000-50,000 manats to 30,000-100,000 manats. Large loans ranging from 50,000 to 200,000 manats increased to 100,001 to 200,000 manats. And finally, loans for the purchase of agricultural machinery up to 1 million manats. The loan repayment period is set from 2 to 5 years.

The agrarian sector is an important component of the country's economy and the non-oil sector. A significant part of the export of the non-oil sector is accounted for by the agricultural sector. Having 
chosen this area as one of the priority policies, the government of the country has implemented a number of measures aimed at supporting and developing the agro-industrial complex in the country.

\section{Results}

Among the main tasks set by the government of Azerbaijan in the development of the agricultural sector is the formation of a modern agro-industrial complex in the country. To form an agro-industrial complex that meets modern requirements, it is necessary to attract new technologies, switch to intensive growth in production volumes, and achieve effective specialization in economic regions. The creation of an agro-industrial complex and large farms is the main formation of a highly productive industry for the production of agricultural products, the compliance of these products with world standards. This condition will contribute to the growth of the country's export potential and its diversification.

There are 6 operating in the country and it is planned to create 3 more agricultural parks. Work on the creation of agricultural parks and large farms is being carried out in 30 regions of Azerbaijan. It should be noted that the state supports this area, allocating millions of manats for the creation of infrastructure and soft loans for this area.In the country, commercial banks support agriculture by issuing loans, including preferential loans for the development of agriculture.

Increasing industrial potential is a priority for the development of Azerbaijan's economy. It should be noted that the presence of a diverse raw material base in the country creates conditions for the development of a diversified industrial complex. It is assumed that the main partners in the export sphere of ferrous metals for Azerbaijan can be such large countries as Great Britain, Russia, Kazakhstan, Turkmenistan, the AOE, and in the field of non-ferrous metals are Iran, China, Turkey and other countries.

Experts believe that ferrous and non-ferrous metallurgy can become one of the export priorities in the non-oil sector. To improve the export potential of the metallurgical industry, you can:

$>$ it is possible to reorganize the existing enterprises of the metallurgical industry;

$>$ attracting both foreign and domestic investments to the metallurgical industry.

$>$ pursuing state policy that stimulates the development of the metallurgical industry. For example, the development of government programs, as well as fiscal and monetary policy measures aimed at the development of these industries.

$>$ production of final goods from products of ferrous and non-ferrous metals, for example, oil engineering, household appliances and other industries associated with the metallurgical industry.

An important area of increasing export potential is the development of the chemical industry. It should be noted that the country had a high potential for the chemical industry, having a sufficient raw material base for diversifying the products of this sector. Currently, the country produces over 100 types of chemical products, most of which are exported. Mainly exported products of the chemical industry include: caustic soda, liquid chlorine, high pressure polyethylene, alcohol, dichloroethane, propylene oxide, polyester resin, chlorine paraffin, heavy and light pyrolysis resin, propylene, butylene, butane-butylene fraction etc. The main importers of chemical products manufactured in Azerbaijan are such countries as the near abroad - Turkey, Russia, Iran, Georgia, Turkmenistan, Ukraine, Kazakhstan, as well as more distant countries - Poland, Egypt, England, Germany and others countries. 


\section{Conclusion and discussion}

Another important area for the development of export potential is the field of information and communication technologies. This industry is a promising, progressive branch of the service sector. The country adopted the State Program for the Development of ICT. The result of the development of this industry was the launch of 3 satellites Azerspace 1, Azerspace 2 and Azerspace 3. Thus, Azerbaijan began to provide high-tech services for export. Currently, there is a growth trend in this type of service in the world, which will contribute to the growth of foreign exchange earnings. The development of ICT in modern conditions is an important condition for increasing the country's export potential, attracting investment and developing innovations. Another important area for the development of export potential is the development of tourism. In this situation, it is expected to attract foreign tourists to the country. The development of tourism does not require the production and transportation of any goods. To ensure the influx of tourists, it is necessary to have hotels, most of which are 5-star hotels in the country, while there are not enough hotels and hostels designed for the average tourist in the country. The development of tourism, in addition to the hotel business, can create related links with such industries as transport, public catering, insurance, as well as the development of various small crafts (workshops) for the production of souvenirs, etc. Thus, the development of tourism, as well as the organization of international conferences in the country, the organization of various kinds of sports competitions, for example, Formula 1 and others, will contribute to the influx of tourists into the country.

As a priority for the non-oil sector, the government has chosen industry, agriculture, transport, information technology, management of foreign exchange reserves, etc.

Studies show that tourism in Azerbaijan is at the stage of development, its indicators are increasing every year. As noted earlier, due to the development of foreign tourism, the export of a number of services in the future can increase the flow of foreign exchange and bring additional profits to the country.

The increase in global demand for chemical products, and the presence in the country of an advantage in several parameters in the production of these products and a number of other factors suggest that the development of the chemical complex, strengthening of state support in this area, and an increase in raw materials supply can contribute to an increase in the export potential of the non-oil sector.

In our opinion, in order to increase the export potential of the country's chemical industry and the export of chemical industry products, it is necessary to take measures in the following areas:

$>$ provision of state support to the chemical industry complexes, application of tax, customs and other benefits;

$>$ opening a line of long-term concessional loans at the expense of state funds;

$>$ modernization of infrastructure serving chemical complexes;

$>$ consideration of the possibilities of attracting foreign investment in large complexes of the chemical industry, which are at the disposal of the state;

$>$ production of modern science-intensive products, etc.

Thus, the conducted research allows us to come to the conclusion that the export of agricultural products, processed products of the agricultural sector, chemical products, metallurgical products are the export priorities of the non-oil sector. However, the development of other sectors of the economy with high export potential can increase the number of such priority areas, and there are many opportunities for this. 


\section{References}

[1] The Key to Social and Economic Transformation. Springer Verlag: Heidelberg, Anderson, T., Curley M.G. and Formica, P.,2010. Knowledge-Driven Entrepreneurship;

[2] Antoncic, B. and Hisrich, R.D., 2003. Clarifying the intrapreneurship concept. Journal of Small Business and Enterprise Development: Bingley;

[3] Franke, N., 2004. Intrapreneurship - Konzept und historischer Bezug. Hernsteiner Fachzeitschrift für Managemententwicklung: Wien;

[4] Holcombe, R.G., 1998. Entrepreneurship and economic growth. The Quaterly Journal of Austrian Economics: Auburn;

[5] Makipere, K. and Yip, G., 2008. Sustainable Leadership. Business Strategy Review: London;

[6] Entrepreneurship Development Fund of the Ministry of Economy of the Republic of Azerbaijan http://edf.gov.az/ (date accessed: 10/06/2021);

[7] Law of the Republic of Azerbaijan on Entrepreneurship, Baku - 1992.

[8] Law of the Republic of Azerbaijan on state support for small business;

[9] Official website of the President of the Republic of Azerbaijan (date accessed: 11/06/2021);

[10] Official website of the State Statistics Committee (date accessed: 12/06/2021);

[11] Regulation on the adoption of "Rules for the determination of large, medium and small entrepreneurship" Decision of the Cabinet of Ministers of 5 June 2015;

[12] State Customs Committee of the Republic of Azerbaijan https://customs.gov.az/az (date accessed: 14/06/2021).

[13] Strategic Road Map for the production and processing of agricultural products in the Republic of Azerbaijan", Baku - 2016;

[14] Strategic Road Map on Production of Consumer Goods at Small and Medium Enterprises in the Republic of Azerbaijan 2016;

[15] Strategic Roadmap for the Development of Logistics and Trade in the Republic of Azerbaijan", Baku 2016;

[16] Strategic Roadmap for the production of consumer goods at the level of small and medium enterprises in the Republic of Azerbaijan, Baku - 2016;

[17] The Constitution of the Republic of Azerbaijan, Baku - 1995;

[18] Approval of the "List of non-oil products to be subject to export promotion by commodity nomenclature of foreign economic activity", Baku - 2016. 